\title{
The histology and the proapoptotic control in the ipsilateral and the contralateral testes following unilateral vasectomy
}

\author{
Aydin Ismet Hazar ${ }^{1}$, Basri Cakiroglu ${ }^{2 *}$, Ertan Sakalli $^{3}$, Mustafa Bahadir Can Balci ${ }^{1}$, \\ Erkan Eyyupoglu ${ }^{4}$, Tuncay Tas ${ }^{1}$, Orhun Sinanoglu ${ }^{5}$, Pinar Tuzlali ${ }^{6}$, Nusret Can Cilesiz ${ }^{1}$ \\ ${ }^{1}$ Taksim Training and Research Hospital, Department of Urology Istanbul, Turkey; \\ ${ }^{2}$ Hisar Intercontinental Hospital, Department of Urology Istanbul, Turkey; \\ ${ }^{3}$ Zonguldak State Hospital, Department of Urology, Zonguldak, Turkey; \\ ${ }^{4}$ Amasya Training and Research Hospital, Department of Urology, Amasya, Turkey; \\ ${ }^{5}$ Maltepe University Medical School, Department of Urology, Istanbul, Turkey; \\ ${ }^{6}$ Taksim Training and Research Hospital, Department of Pathology, Istanbul, Turkey
}

\begin{abstract}
Summary Objective: The aim of this study was to enlighten both the testicular histology and the genetic aspects of the apoptotic process. Thus an experimental study was designed with a model of unilateral vasectomy.

Methods: Twenty-two adult male rats were used and 4 main groups were formed. The first (A), the second (B), the third (C), and the fourth group (D) consisted of 4, 4, 4 and 10 rats respectively. Rats in group $A$ had sham operation while rats in other groups $(B, C, D)$ underwent left vasectomy operation including binding of ductus deferens with a 3/0 silk and cutting a minimum of $1 \mathrm{~cm}$ part while preserving the vascular structure under 9x magnification. Rats undergoing unilateral vasectomy were sacrificed at the $1^{\text {st }}, 2^{\text {nd }}$ and $8^{\text {th }}$ weeks and their testicular structure and proapoptotic gene proteins were compared with that of the control group undergoing sham operation.

Results: We found that vasectomy gradually caused destruction and both ipsilateral and contralateral testicles were affected showing initial apoptosis.

Conclusion: The procedure causes destruction in the testicular structure by causing bilateral intratubular germ cell necrosis, unilateral obstruction, increase in the tubular pressure and processes that are aggravated by some probable autoimmune reactions.
\end{abstract}

KEY WORDS: Testis; Spermatogenesis; Vasectomy; Apoptosis; BCL-2 protein.

Submitted 18 December 2014; Accepted 31 March 2015

\begin{abstract}
INTRODUCTION
Spermatogenesis is a process in which spermatogonial stem cells form mature sperm cells (spermatozoa) by cell differentiation which is characterized by mitotic and meiotic cell divisions. Germ cell deaths occur in addition to cell growth and proliferation during normal spermatogenesis which is of critical importance in the formation of the mature sperm cells (1). Apoptosis is the process that destructs the cells with a damaged DNA after receiving internal or external induction signals. The effectors of this death process are the caspases and the Bcl-2 protein family which is responsible for 17 p53
\end{abstract}

gene's pro regulation, and they have great importance in the modulation of this process (2-4). Since it was first detected in B cell lymphoma-2 cells it was named as BCL-2. Some proteins of the BCL-2 gene family such as "bcl-2, bcl-xL and bcl-w" support cell growth and play an apoptotic role while others such as "bax, bam, bad, bok, bid and bim" antagonise the effect of others and play an apoptotic role (5). The competition between these two cells and their being a homodimer such as bcl/bcl, bax/bax or a heterodimer such as bax/bcl assign the cell either to die or to live $(6,7)$. The naming "bax" is formed as bcl-2 associated $\mathrm{x}$ protein and is based on the ralationship between these two immunohistochemical (IHC) measurements of the proapoptotic and antiapoptotic proteins are used in determining the apoptosis as well as the detection of the DNA fragmantation (8). Bax overexpression has been shown with drug-induced apoptosis in human germ cells (9). The same finding was found in animal experiments after vasectomy $(10,11)$.

Although vasectomy is a popular male contraception method and its reversals have been widely studied, the effect of vasectomy on testicular histology is still controversial $(12,13)$. However, even apoptosis in the ejaculate has been studied in diabetes, schizophrenia and in immunopathologies (14) the relationship between the post vasectomial testicular histology and apoptosis and its clinical effects haven't been studied widely (8, 15-18). In this study adult rat unilateral vasectomy was compared with the control group and the answer to 4 questions were required: 1) the role of vasectomy on testicular damage 2) its genetic effect based on bax in apoptosis in normal spermatogenesis 3 ) the effects of vasectomy on the contralateral testicle 4) the possible effects of the unilateral vas deferens damage due to inguinal surgery on testicular histopathology.

\section{Materials AND Methods}

In this experimental study, 22 adult male Sprague Dawley 16 weeks old rats weighing 250 grams were used and studied in 4 main groups. The first group (A) consisted of 4 rats, the second (B) 4 , the third (C) 4 and the fourth 
group (D) 10 rats. All the rats had anesthesia with intraperitoneal $25 \mathrm{mg} / \mathrm{kg}$ pentothal injection. While rats in group A had sham operation in an aseptic environment, rats in group B, C, D had a left vasectomy operation in which ductus deferens was tied with a 3/0 silk and a minimum of $1 \mathrm{~cm}$ part was excised with an inguinal incision preserving the vascular structure. Animals were sacrificed with $75 \mathrm{mg} / \mathrm{kg}$ pentothal injection and standard orchiectomy was applied and the testicular histopathology was examined at the $1^{\text {st }}(\mathrm{B})$, the $2^{\text {nd }}(C)$ and the $8^{\text {th }}(D)$ week.

\section{Histopathology}

The testes were fixed in Bouin solution and buried in paraffin and sections were prepared from tissue blocks. All the samples were examined for inflamatory infiltrate, edema, fibrosis, sperm granuloma, intratubular spermatic necrosis.

\section{IHC Coloring}

Bax B-9 rat monoclonal IgG2b antibody which is essential for coloring was used. Bax protein eliminates the inhibitory effects of BCL-2 gene and speeds up apoptotic deaths, thus Bax antibody binds to the Bax protein in the cell in which the apoptotic death is increased.

In the beginning of the procedure, tissue sections were incubated in hydrogen peroxidase solution for $15 \mathrm{~min}$ utes then washed with Phosphate Buffer Saline (PBS) twice, citrate tamponade was made in microwave and then cooled in room temperature for 20 minutes, afterwards washed with PBS for four times. In order to avoid non specific arka plân coloring, ultra V Block application (Protein blockage) was made in room temperature for 5 minutes. It was not washed, but Bax antibody was used to cover the tissue by dropping the Ultra V Block onto the microscope slide and incubated for an hour. Dilution was made at $1 / 100$. Then it was washed with PBS for 4 times. Afterwards "Biotinylated Goat Anti polyvalent Solution" (link saru) was dropped and after 20 minutes was washed with PBS for 4 times and incubated with AEC Chromogen until it was colored (AEC preparation: 1 drop of chromogen was added to $1 \mathrm{ml}$ of substrate and washed with distilled water).

The contrast coloring was made with Mayer's Haematoxylin that was kept there for 1 minute maximum before being washed with distiled water and closed with ultramount. Preparates were examined with a light microscope and Bax (+) coloring was defined as granular type coloring of the cytoplasm. Increased intensity of coloring $(+)$, excessive increase in coloring $(++)$ and normal coloring were recorded. Randomized 10 tubules diameters were measured in all the samples under the ocular micrometer of the Olympus CH3O light microscope. Necrosis level of intratubular germ cells were classified according to their cell level.

\section{Statistical analysis}

Kruskal Wallis test was used to compare groups, MannWhitney $U$ test was used for dual comparisons and Fisher (exact) test was used to compare the qualitative data. All the results were evaluated in a CI of $95 \%$ and $\mathrm{p}<0.05$ was defined as statistical significance.

\section{RESULTS}

After the IHC, all four groups were evaluated for apoptosis and morphology and these results were found: all 4 cases in the control group had spontaneous apoptosis and apoptotic coloring was dominant (+) in the spermatocyte level in 3 cases and in the spermatid level in 1 case. At the $1^{\text {st }}$ week of the unilateral vasectomy bax coloring level increased to $(++)$ while it remained the same $(+)$ in one case. Dominant level was the spermatocyte level, the same as the control group. On the contralateral side bax coloring was $(+)$ but in 3 cases bax dominant cell level had increased to spermatids while in one case it remained in the spermatocyte level. At the $2^{\text {nd }}(C)$ and the $8^{\text {th }}$ weeks (D) bax colorings were negative both in the vasectomy operated side and the contralateral side. The difference in the bax positivity in the vasectomy operated testes were statistically significant when compared with the $2^{\text {nd }}$ and the 8 th weeks. Likewise $1^{\text {st }}$ week's bax positivity of the contralateral side was statistically significant when compared to that of the $2^{\text {nd }}$ and the 8 weeks (Table 1 ).

During the first week, neither the ipsilateral nor the contralateral testicles had any inflammation. At the second week 3 of the ipsilateral testicles had inflamation of the tunica albuginea while there were no such inflammation in the contralateral testis. At the $8^{\text {th }}$ week inflammation was detected in 4 vasectomy operated testes and in 2 contralateral testes. When the inflammation rate of the first

\section{Table 1.}

Weekly Bax staining results.

\begin{tabular}{|c|c|c|c|}
\hline \multicolumn{2}{|l|}{ Control } & \multirow{2}{*}{$\begin{array}{c}\text { Bax } \\
(+) \\
(+)\end{array}$} & \multirow{2}{*}{$\begin{array}{c}\text { Bax cell (dominant) } \\
\text { Spermatocyte } \\
\text { Spermatocyte }\end{array}$} \\
\hline Case 1 & $\begin{array}{l}\text { Left testis } \\
\text { Right testis }\end{array}$ & & \\
\hline Case 2 & $\begin{array}{l}\text { Left testis } \\
\text { Right testis }\end{array}$ & $\begin{array}{l}(+) \\
(+)\end{array}$ & $\begin{array}{l}\text { Spermatocyte } \\
\text { Spermatocyte }\end{array}$ \\
\hline Case 3 & $\begin{array}{l}\text { Left testis } \\
\text { Right testis }\end{array}$ & $\begin{array}{l}(+) \\
(+)\end{array}$ & $\begin{array}{l}\text { Spermatocyte } \\
\text { Spermatocyte }\end{array}$ \\
\hline Case 4 & $\begin{array}{l}\text { Left testis } \\
\text { Right testis }\end{array}$ & $\begin{array}{l}(+) \\
(+)\end{array}$ & $\begin{array}{c}\text { Spermatid } \\
\text { Spermatocyte }\end{array}$ \\
\hline $1^{\text {st }}$ Week & & & \\
\hline Case 1 & $\begin{array}{l}\mathrm{V} 1 \\
\mathrm{C} 1\end{array}$ & $\begin{array}{c}(++) \\
(+)\end{array}$ & $\begin{array}{l}\text { Spermatocyte } \\
\text { Spermatid }\end{array}$ \\
\hline Case 2 & $\begin{array}{l}\text { V2 } \\
\text { C2 }\end{array}$ & $\begin{array}{c}(++) \\
(+)\end{array}$ & $\begin{array}{l}\text { Spermatocyte } \\
\text { Spermatocyte }\end{array}$ \\
\hline Case 3 & $\begin{array}{l}\text { V3 } \\
\text { C3 }\end{array}$ & $\begin{array}{c}(++) \\
(+)\end{array}$ & $\begin{array}{l}\text { Spermatocyte } \\
\text { Spermatid }\end{array}$ \\
\hline Case 4 & $\begin{array}{l}\text { V4 } \\
\text { C4 }\end{array}$ & $\begin{array}{l}(+) \\
(+)\end{array}$ & $\begin{array}{l}\text { Spermatocyte } \\
\text { Spermatid }\end{array}$ \\
\hline $2^{\text {nd }}$ Week & & & \\
\hline Case 1 & $\begin{array}{l}\mathrm{V} 1 \\
\mathrm{C} 1\end{array}$ & $\begin{array}{l}(-) \\
(-)\end{array}$ & $\begin{array}{l}(-) \\
(-)\end{array}$ \\
\hline Case 2 & $\begin{array}{l}\mathrm{V} 2 \\
\mathrm{C} 2\end{array}$ & $\begin{array}{l}(-) \\
(-)\end{array}$ & $\begin{array}{l}(-) \\
(-)\end{array}$ \\
\hline Case 3 & $\begin{array}{l}\text { V3 } \\
\text { C3 }\end{array}$ & $\begin{array}{l}(-) \\
(-)\end{array}$ & $\begin{array}{l}(-) \\
(-)\end{array}$ \\
\hline Case 4 & $\begin{array}{l}\text { V4 } \\
\text { C4 }\end{array}$ & $\begin{array}{l}(-) \\
(-)\end{array}$ & $\begin{array}{l}(-) \\
(-)\end{array}$ \\
\hline
\end{tabular}


Table 2.

Weekly histopathology results.

\begin{tabular}{|c|c|c|c|c|c|c|c|}
\hline $1^{\text {st }}$ Week & \multicolumn{3}{|c|}{ Inflammation } & Pt fibrosis & \multicolumn{2}{|c|}{ Intratubular necrosis } & Sperm granuloma \\
\hline$\overline{\mathrm{V} 1}$ & \multicolumn{3}{|c|}{$(-)$} & $(+)$ & \multicolumn{2}{|r|}{$(-)$} & $(-)$ \\
\hline $\mathrm{C1}$ & \multicolumn{3}{|c|}{$(-)$} & $(-)$ & \multicolumn{2}{|r|}{$(-)$} & $(-)$ \\
\hline V2 & \multicolumn{3}{|c|}{$(-)$} & $(-)$ & \multicolumn{2}{|r|}{$(-)$} & $(-)$ \\
\hline $\mathrm{C} 2$ & \multicolumn{3}{|c|}{$(-)$} & $(-)$ & \multicolumn{2}{|r|}{$(-)$} & $(-)$ \\
\hline V3 & \multicolumn{3}{|c|}{$(-)$} & $(-)$ & \multicolumn{2}{|r|}{$(-)$} & $(-)$ \\
\hline $\mathrm{C} 3$ & \multicolumn{3}{|c|}{$(-)$} & $(-)$ & \multicolumn{2}{|r|}{$(-)$} & $(-)$ \\
\hline V4 & \multicolumn{3}{|c|}{$(-)$} & $(-)$ & \multicolumn{2}{|r|}{$(-)$} & $(-)$ \\
\hline $\mathrm{C} 4$ & \multicolumn{3}{|c|}{$(-)$} & $(-)$ & \multicolumn{2}{|r|}{$(-)$} & $(-)$ \\
\hline \multirow[t]{2}{*}{$1^{\text {st }}$ Week } & \multirow{2}{*}{\multicolumn{3}{|c|}{ Inflammation }} & Pt fibrosis & \multicolumn{2}{|c|}{ Intratubular necrosis } & Sperm granuloma \\
\hline & & & & & Degree & Dominant & \\
\hline$\overline{\mathrm{V} 1}$ & \multicolumn{3}{|c|}{$(-)$} & $(-)$ & $(++)$ & $2^{\circ}$ spermatocyte & $(-)$ \\
\hline $\mathrm{C} 1$ & \multicolumn{3}{|c|}{$(-)$} & $(-)$ & $(-)$ & $(-)$ & $(-)$ \\
\hline V2 & \multicolumn{3}{|c|}{ (+)T.Albuginea } & $(+)$ & $(++)$ & Spermatid & $(+)$ \\
\hline $\mathrm{C} 2$ & \multicolumn{3}{|c|}{$(-)$} & $(-)$ & $(-)$ & $(-)$ & $(-)$ \\
\hline V3 & & (+)T.Alb & inea & $(+)$ & $(+)$ & $2^{\circ}$ spermatocyte & $(-)$ \\
\hline C3 & & $(-)$ & & $(-)$ & $(-)$ & $(-)$ & $(-)$ \\
\hline V4 & & (+)T.Alb & inea & $(-)$ & $(t+)$ & Spermatid & $(-)$ \\
\hline $\mathrm{C} 4$ & & $(-)$ & & $(-)$ & $(-)$ & $(-)$ & $(-)$ \\
\hline $8^{\text {th }}$ Week & & Intra & bular & lecrosis & Pt fibrosis & Sperm granuloma & Inflammation \\
\hline & & Degree & & minant & & & \\
\hline Case 1 & V1 & $(+)$ & $1^{\circ} \mathrm{sp}$ & rmatocyte & $(-)$ & $(-)$ & $(+)$ \\
\hline & & $(++)$ & & ermatid & $(-)$ & $(-)$ & $(-)$ \\
\hline Case 2 & V2 & $(++)$ & $2^{\circ} \mathrm{sp}$ & ermatocyte & $(+)$ & $(+)$ & $(-)$ \\
\hline & & $(++)$ & & perma & $(-)$ & $(-)$ & $(-)$ \\
\hline Case 3 & V3 & $(++)$ & $2^{\circ} \mathrm{S}$ & ermatosit & $(-)$ & $(+)$ & $(+)$ \\
\hline & C3 & $(++)$ & & ermatid & $(-)$ & $(-)$ & $(-)$ \\
\hline Case 4 & V4 & $(+++)$ & $2^{\circ} \mathrm{sp}$ & rmatocyte & $(-)$ & $(-)$ & $(-)$ \\
\hline & & $(+)$ & & ermatid & $(-)$ & $(+)$ & $(-)$ \\
\hline Case 5 & & $(++)$ & $2^{\circ} \mathrm{sp}$ & rmatocyte & $(-)$ & $(-)$ & $(-)$ \\
\hline & C5 & $(++)$ & & perma & $(-)$ & $(-)$ & $(-)$ \\
\hline Case 6 & & $(+)$ & $2^{\circ} \mathrm{sp}$ & rmatocyte & $(+)$ & $(+)$ & $(+)$ \\
\hline & & $(++)$ & & perma & $(-)$ & $(-)$ & $(+)$ \\
\hline Case 7 & & $(++)$ & & ermatid & $(-)$ & $(-)$ & $(-)$ \\
\hline & & $(++)$ & & ermatid & $(-)$ & $(-)$ & $(-)$ \\
\hline Case 8 & V8 & $(+++)$ & $2^{\circ} \mathrm{sp}$ & rmatocyte & $(-)$ & $(-)$ & $(-)$ \\
\hline & & $(+)$ & & ermatid & $(-)$ & $(-)$ & $(-)$ \\
\hline Case 9 & & $(++)$ & $2^{\circ} \mathrm{sp}$ & armatocyte & $(-)$ & $(-)$ & $(+)$ \\
\hline & $\mathrm{Cg}$ & $(-)$ & & $(-)$ & $(-)$ & $(-)$ & $(+)$ \\
\hline Case 10 & V10 & $(-)$ & & $(-)$ & $(-)$ & $(-)$ & $(-)$ \\
\hline & C10 & $(+)$ & $2^{\circ} \mathrm{sp}$ & rmatocyte & $(-)$ & $(-)$ & $(-)$ \\
\hline
\end{tabular}

$1^{\text {st }}, 2^{\text {nd }}$ and $8^{\text {th }}$ week when compared to the contralateral testicles $(\mathrm{p}<0.0001)$.

Intratubular germ cell necrosis was not detected during the $1^{\text {st }}$ week. At the $2^{\text {nd }}$ week, 4 cases had moderate and 1 case had mild intratubular germ cell necrosis while it was not seen in the contralateral side. Dominant level was the spermatocyte level in 2 cases and the spermatid level in 2 cases. At the $8^{\text {th }}$ week 9 out of 10 testes with vasectomy had intratubular germ cell necrosis. Intratubular germ cell necrosis was mild in 2 cases, moderate in 5 cases and severe in 2 cases. Dominant level was the $1^{\circ}$ spermatocyte level in 1 case, the $2^{\circ}$ spermatocyte level in 7 cases and the spermatid level in 1 case. When the contralateral testes were examined intratubular germ cell necrosis was found in 9 out of 10 cases. In 6 cases it was moderate and in 3 cases it was mild. Dominant level was the spermatid level in 5 cases, the $1^{\circ}$ spermatocyte level in 3 cases and $2^{\circ}$ spermatocyte level in 1 case (Table 2).

Statistical analyses revealed that germ cell necrosis mainly in the spermatid area was statistically significant at the $2^{\text {nd }}$ week when compared with that of the $8^{\text {th }}$ week $(p<0.0001)$. There was statistically significant increase in intratubular germ necrosis at the $2^{\text {nd }}$ and the $8^{\text {th }}$ week when compared with the 1st week $(p<0.001)$. When the contralateral testicles were evaluated internally, increase in germ cell necrosis in spermatids at the $8^{\text {th }}$ week was statistically significant $(\mathrm{p}<0.0001)$.

In the preoperative operation no sperm granuloma was seen while it was encountered in one case at the $2^{\text {nd }}$ week and in 3 cases at the $8^{\text {th }}$ week. When compared with the 1st week, the possibilty of granuloma detection rate was higher at the $2^{\text {nd }}$ and the $8^{\text {th }}$ week and this difference was statistically significant $(\mathrm{p}<0.0001)$. No testicular necrosis or atrophy were shown.

The morphology of the epididymis was pre-

week was compared with the patients $2^{\text {nd }}(p<0.0001)$ and the $8^{\text {th }}$ week $(\mathrm{p}<0.001)$ statistically significant increase was detected. When the contralateral testicles were evaluated, no such increase according to weeks was detected $(p>0.05)$. When the ipsilateral and the contralateral testes were compared there were no statistically significant difference at the $1^{\text {st }}$ week $(\mathrm{p}>0.05)$ but at the end of the $2^{\text {nd }}$ and the $8^{\text {th }}$ week, inflammation rate was higher in the vasectomy operated group $(\mathrm{p}<0.001)$ (Table 2$)$.

Peritubular fibrosis was seen in the vasectomy operated group at the first week and 2 cases at the $2^{\text {nd }}$ and $8^{\text {th }}$ week while it wasn't seen in any in the contralateral group. While there was a significant rise in peritubular fibrosis at $2^{\text {nd }}$ weeks when compared with the $1^{\text {st }}$ week $(p<0.01)$, there was no significant increase at $8^{\text {th }}$ week when compared to the $2^{\text {nd }}$ ( $\left.p>0.05\right)$. In the vasectomy group peritubular fibrosis was significantly higher at the served at the $8^{\text {th }}$ week.

The diameter of the tubules was $235.3 \pm 12.9 \mu$ in the vasectomy operated side and $248 \pm 12.9 \mu$ in the contralateral side at the 1st week. In the second week the mean diameter of the tubule in the vasectomy operated testicle was $234.5 \pm 3.87 \mu$ and the mean diameter of the contralateral side was $249.3 \pm 3.20 \mu$. At the $8^{\text {th }}$ week this diameter was measured as $230.1 \pm 7.66 \mu$ in the ipsilateral side and $250.4 \pm 2.5 \mu$ in the contralateral side. When the statistical analyses were made for the mean tubule diameters and weekly change, the difference was not statistically significant at the $1^{\text {st }}$ week $(p>0.05)$ while it was statistically significant at the $2^{\text {nd }}(\mathrm{p}<0.05)$ and the $8^{\text {th }}$ week $(\mathrm{p}<0.001)$.

There was no statistically significant difference when the vasectomy operated testes were compared with each other $(p>0.05)$ (Table 3$)$. 
Table 3.

The testicular tubular diameter change per weeks in the ipsilateral and contralateral testi.

\begin{tabular}{|lccccc|}
\hline Tubule diameters & $\mathbf{1}^{\text {st }}$ Week & $\mathbf{2}^{\text {nd }}$ Week & $\mathbf{8}^{\text {th }}$ Week & KW & pV1 \\
\hline Vasectomy & $235.3 \pm 12.09$ & $234.5 \pm 3.87$ & $230.1 \pm 7.66$ & 1.38 & $>0.05$ \\
\hline Contralateral testes & $248 \pm 3.91$ & $249.3 \pm 3.20$ & $250.4 \pm 2.5$ & 2.54 & $>0.05$ \\
\hline $\mathrm{MW}$ & 2 & 0 & 0 & & \\
\hline $\mathrm{p}$ & $>0.05$ & $<0.05$ & $<0.001$ & & \\
\hline
\end{tabular}

the granulomas relieve the inflamatory pressure. It may be related to intraluminar phagocytosis. Phagocytosis causes stimulation of the immune system which cause antisperm antibodies formation. On the other hand it is also possible that extravasation may induce autoimmune responses. There are many articles about the autoimmune response to the testicular tissue. T lymphocytic cells and monocytes are responsible from this immunity and phagocytosis. After detecting the antigen, T lymphocytic cells

\section{Discussion}

The effect of vasectomy on testicular histology is still controversial. Testicular stem cells and spermatids which are formed by differentiated stem cells are in close relationship with the seminifer tubules' luminar cells and Sertoli cells of the testicular interstitium. In order to maturize to sperm cells they need the epididymis and its functions as well. The high rate of fertilisation in conductive fertilisation techniques after vasectomy and its reversals suggest that vasectomy does not cause an important disorder in testicular functions.

Althrough the studies in the literature are controversial, there is more data supporting that there is a worsening of the sperm functions and dilatation in the seminiferous tubules in the early stages and inflammation and peritubular fibrosis with a decrease in germ cell levels in the later stages (19). Spermatic cysts behave as shock absorbers and help in preserving the functions and give physiological support (20). Lower fertilization rates in patients with short-term vasectomy than in patients with long-term vasectomy support the late stage findings of testicular histology. Recent studies have shown that apoptosis is the most important mechanism for spermatogenesis in germ cells. Apoptosis has been widely studied in the spermatogonia, the spermatocytes and spermatids and, many apoptotic factors have been described. Testicular germ cell apoptosis is a physiological event that occurs throughout life (21). In the end the number of potential spermatozoa decrease by $75 \%$. Apoptosis has 2 functions in spermatogenesis. The first is to limit the germ cell population which Sertoli cells can support, the second is to be selective in decreasing the abnormal spermatozoa (21). The relationship between the fertility and apoptosis was shown by the increased apoptosis in patients with oligospermia. On the other hand there are few studies regarding the effect of vasectomy on this process and its genetic control. There's almost no studies on the apoptotic process in normal testicles. Its clinical importance is the potential effect on fertility in vas deferens injuries that does not last with orchiectomy.

We did not detect any testicular necrosis or atrophy in our experimental study. But there were increase in sperm granuloma formations and significant increase in tubular diameters and decrease in the wall thickness. The increase of the granuloma is more significant at the $8^{\text {th }}$ week. Since spermatogenesis continues after vasectomy, there can be leaks from the slimming tubules due to the widening of the epididymis and ductus deferens and this stimulates the granuloma formation. It is possible that stimulate B lymphocytic cells to produce antibodies. Monocyte-monocyte interaction leads the phagocytosis pathway to activate and this formation causes inflammation and fibrosis in testicular germ cells (22). In our study in the later stages at the $8^{\text {th }}$ week in 9 out of 10 cases intratubular germ cell necrosis was present in vasectomy operated side, in addition to inflammation and fibrosis, 2 cases had mild, 5 cases had moderate and 2 cases had severe intratubular germ cell necrosis. Dominant stage was the $1^{\circ}$ spermatocyte in one case, the $2^{\circ}$ spermatocyte in 7 cases and the spermatid in one case. Studies that explain the impairment in spermatogenesis after iatrogenic damage to vas deferens are classified as: 1) immunologic response to the testicular tissue 2) reactive oxygen species 3) apoptotic changes in germ cells (23-26). However, it is also suggested that adult vas deferens obstruction does not affect apoptosis (27).

Abnormal spermatogenesis was shown to occur due to dysfunctional expression of the genes (28-34). In our study we observed that increased apoptosis in the testis undergoing vasectomy This is compatible with previous literature findings (35). Thus, with our vasectomy experiment protocol, we tried to find an answer to 2 main questions which include the changes in the ipsilateral histology and apoptosis.

Bax staining increased in the contralateral testicle during the initial period in our vasectomy model. The affected cell level was more mature in contrast to the ipsilateral testicle. It is known that apoptosis in stem cells affects the physiological regulation. Despite the fact, this high apoptosis level in the low-resistant spermatids which are under high exposure to external factors in the contralateral testicle suggest a possible systemic effect after vasectomy $(36,37)$.

This early stage of apoptosis occurs without intratubular and peritubular changes and the granuloma formation may not be dependent on the immunity. We found findings suggesting that this effect supports the late stage inflammation. We believe that Bax proteins has a role in this modulation. We did not detect any tubular or peritubular pathologies in the contralateral testis since the increase of pressure does not affect the contralateral one. If these findings with common avascular fibrosis which is seen during the complete mobilization of vas deferens in inguinal surgery was further evaluated, it may enlighten the underlying factors of this situation which causes sterility with a range of $78 \%$. Furthermore, the excessive mobilization of the cord and the operation technique are highly important in the inguinal surgery in order to sustain fertility (38). 


\section{Conclusions}

The damage in testicular histology following the obstruction of ductus deferens depends by complex mechanisms rather than a single mechanism. Apoptosis is responsible for the initial germinal cell damage. Unilateral ductal obstruction causes damage on the testicular structure by causing bilateral germ cell necrosis due to the increase in pressure and processes that are triggered by the autoimmune reactions. We have shown that it is not essential to initiate the immune reaction for the sperm granuloma formation and vasectomy alone can trigger the immune response and impair the spermatogenesis.

\section{AUthors' CONTRIBUTIONS}

$\mathrm{AIH}, \mathrm{BC}$ and $\mathrm{MBCB}$ and conducted the experiments and participated in acquisition, analysis, and interpretation of data. SEE and TT participated in analysis and interpretation of data, and drafted the manuscript. OS and NCC helped in analyzing the data and in drafting the manuscript. PT drew the study conception and design, participated in revising the manuscript critically for important intellectual content and has given the final approval of the version to be submitted. All authors read and approved the final manuscript.

\section{ACKNOWLEDGEMENT}

We thank Pathology Laboratory, Taksim Training and Research Hospital for laboratory facilities, technical assistance and financial aid.

\section{References}

1. Vera Y, Rodriguez S, Castanares M, et al. Functional role of caspases in heat-induced testicular germ cell apoptosis. Biol Reprod. 2005; 72:516-22.

2. Beroud C and Soussi T. P53 gene mutation soft ware and database. Nucleic Cad. Res. 1998; 26:200-204.

3. Tsujimoto Y. Role of Bcl-2 family of proteins in apoptosis, apoptosomes or mitochondria? Genes Cell 1998; 3:697-707.

4. Taneja N, Tjalkens R, Philbert MA, et al. Irradiation of mitochondria initiates apoptosis in a cell free system. Oncogene. 2001; 20:167-77.

5. Adams JM and Cory S. The Bcl-2 protein family: arbiters of cell survival. Science 1998; 281:1322-26.

6. Basu A, Haldar S. The relationship between BcI2, Bax andp53: consequences for cell cycle progression and cell death. Mol Hum Reprod. 1998; 4:1099-109.

7. Oltvai ZN, Milliman CL and Korsmeyer SJ. Bcl-2 heterodimerizes in vivo with a conserved homolog, Bax, that accelerates programmed cell death. Cell 1993; 74:609-19.

8. hukla KK, Mahdi AA, Rajender S. Apoptosis, spermatogenesis and male infertility. Front Biosci. 2012; 4:746-54.

9. Boersma AW, Nooter K, Burger H, et al. Bax upregulation is a nearly event in cisplatin-induced apoptosis in human testicular germ cell tumor cell line NT2, as quantitated by flow cytometry. Cytometry 1997; 27:275-82.

10. Shiraishi K, Naito K andYoshida K. Vasectomy impairs sper- matogenesis through germ cell apoptosis mediated by the p53-Bax pathway in rats. J Urol. 2001; 166:1565-71.

11. Al-Maghrebi M, Kehinde EO and Anim JT. Survivin downregulation is associated with vasectomy-induced spermatogenic damage and apoptosis. Med Princ Pract. 2011; 20:449-54.

12. Handelsman D and Waites G. Traditional methods. In: Schill W, Comhaive F, Hargreave T, editors. Andrology for the Clinician. Berlin: Springer Verlag; 2006. pp. 122-124.

13. Mui P, Perkins A, Burrows PJ, et al. The need for epididymovasostomy at vasectomy reversal plateaus in older vasectomies: a study of 1229 cases Andrology. 2014; 2:25-9.

14. Li A, Ojogho O, Escher A. Saving death: apoptosis for intervention in transplantation and autoimmunity. Clin. Dev. Immunol. 2006; 13:273-82.

15. Lopes S, Jurisicova A, Sun JG, et al. Reactive oxygen species: potential cause for DNA fragmentation in human spermatozoa. Hum. Reprod 1998; 13:896-900.

16. Donnelly ET, O'Connell M, McClure N, et al. Differences in nuclear DNA fragmentation and mitochondrial integrity of semen and prepared human spermatozoa. Hum. Reprod. 2000; 15:1552-1561.

17. Glander HJ and Schaller J. Binding of Annexin V to plasma membranes of human spermatozoa: a rapid assay for detection of membrane changes after cryostorage. Mol. Hum. Reprod 1999; 5:109-115

18. Huszar G, Stone K, Dix D, Vigue L. Putative creatine kinase Misoform in human sperm is identified as the 70-kilodalton heat shock protein HspA2. Biol Reprod.2000; 63:925-32.

19. Raleigh D, O'Donnell L, Southwick GJ, et al. Stereological analysis of the human testis after vasectomy indicates impairment of spermatogenic efficiency with increasing obstructive interval. Fertil Steril. 2004; 81:1595-603.

20. Kuwahara M, Frick J. The ligation of the male reproductive organs and the role of the spermatic cyst. Andrologia. 1975; 7:1-14.

21. Seli E, Sakkas D. Spermatozoal Nuclear Determinants of Reproductive Outcome: Implications For ART. Hum. Reprod Update. 2005; 11:337-349.

22. Helming L, Gordon S. Macrophage fusion induced by IL-4 alternative activation is a multistage process involving multiple target molecules. Eur J Immunol. 2007; 37:33-42.

23. Sharma RK, Pasqualotto FF, Nelson DR, et al. The reactive oxygen species-total antioxidant capacity score is a new measure of oxidative stress to predict male infertility.Human Reproduction 1999; 14:2801-2807.

24. Lopes S, Jurisicova A, Sun JG, Casper RF. Reactive oxygen species: potential cause for DNA fragmentation in human spermatozoa .Hum Reprod. 1998; 13:896-900

25. Zhang Y, Tocchetti CG, Krieg T, et al. Oxidative and nitrosative stress in the maintenance of myocardial function. Free Radical Biology and Medicine. 2012; 53:1531-1540.

26. Zhang $Y$, Wang X, Chen Z, et al. Long-term reproductive consequences of no-scalpel vasectomy in beagles. J Huazhong Univ Sci Technolog Med Sci.2012; 32:899-905.

27. Inaba Y, Fujisawa M, Okada $H$, et al. The apoptotic changes of testicular germ cells in the obstructive azoospermia models of prepubertal and adult rats. J Urol. 1998; 160:540-4.

28. Krajewski S, Krajewska M, Shabaik A, et al. Immunohistochemical determination of in vivo distribution of Bax, adominant inhibitor of Bcl-2. Am J Pathol 1994; 145:1323-1336. 
29. Watanabe M, Shirayoshi Y, Koshimizu U, et al. N. Gene transfection of Mouse primordial germ cells in vitro and analysis of their survival and growth control. Exp Cell Res 1997; 230:76-83.

30. Furuchi T, Masuko K, Nishimune Y, et al. Inhibition of testicular germ cell apoptosis and differentiation in mice misexpressing Bcl-2 in spermatogenesis. Development 1996; 122:1793-1709.

31. Knudson CM, Tung KS, Tourtellotte WG, et al. Baxdeficient mice with lymphoid hyperplasia and male germ cell death. Science 1995; 270:96-9.

32. Krajewski S, Krajewska M, Shabaik A, et al. Immuno histochemical analysis of in vivo patterns of Bcl-X expression. Cancer Res. 1994; 54:5501-7.

33. Furuchi T, Masuko K, Nishimune Y, et al. Inhibition of testiculargerm cell apoptosis and differentiation in mice misexpressing Bcl2 in spermatogonia. Development 1996; 122:1703-9.
34. Ross AJ, Waymire KG, Moss JE, et al. Testicular degeneration inBclw-deficient mice. Nat Genet 1998; 18:251-6.

35. McVicar CM, O'Neill DA, McClure N, et al. Effects of vasectomy on spermatogenesis and fertility outcome after testicular sperm extraction combined with ICSI. Human Reproduction 2005; 20,2795-2800.

36. Pérez-Crespo M, Pintado B, Gutiérrez-Adán A. Scrotal heat stress effects on sperm viability, sperm DNA integrity, and the offspring sex ratio in mice. Mol Reprod Dev. 2008; 75:40-7.

37. Billig H, Furuta I, Rivier C, et al. Apoptosis in testis germ cells: developmental changes in gonadotropin dependence and localization to selective tubule stages. Endocrinology. 1995; 136:5-12.

38. Matsuda T, Muguruma K, Horii Y, et al. Serum antisperm antibodies in men with vas deferens obstruction caused by childhood inguinal herniorhaphy. Fertil Steril 1993; 59:1095.

\section{Correspondence}

Aydin Ismet Hazar, MD

Mustafa Bahadir Can Balci, MD

Tuncay Tas, MD

Nusret Can Cilesiz, MD

Taksim Training and Research Hospital, Department of Urology, Istanbul, Turkey

Basri Cakiroglu, MD (Corresponding Autor)

drbasri@hotmail.com

Hisar Intercontinental Hospital Department of Urology

Saray Mah. Siteyolu Cad., No:7 34768 Umraniye, Istanbul, Turkey

Ertan Sakalli, MD

Zonguldak State Hospital, Department of Urology, Zonguldak, Turkey

Erkan Eyyupoglu, MD

Amasya Training and Research Hospital, Department of Urology, Amasya, Turkey

Orhun Sinanoglu, MD

Maltepe University Medical School, Department of Urology, Istanbul, Turkey

Pinar Tuzlali, MD

Taksim Training and Research Hospital, Department of Pathology, Istanbul, Turkey 